\title{
VALUES OF HAEMATOLOGICAL INDICES OF WELS (Silurus glanis L.) IN RELATIONSHIP TO THE LEVEL OF NUTRITION DURING THE PRE-SPAWNING PERIOD
}

\author{
Z. SVOBODOVÁ ${ }^{1.2}$, J. KOLÁR̆OVÁ ${ }^{1}$, H. MODRÁ ${ }^{2}$, V. VAJCOVÁ ${ }^{1}$, J. HAMÁČKOVÁ \\ J. KOUŘIL'. P. KOZÁK ${ }^{1}$ \\ ${ }^{1}$ Research Institute of Fish Culture and Hydrobiology, University of South Bohemia. Vodňany, \\ ${ }^{2}$ University of Veterinary and Pharmaceutical Sciences, Brno, Czech Republic
}

Received July 30, 1998

Accepted September 21, 1998

\begin{abstract}
Svobodová, Z., J. Kolářová, H. Modrá, V. Vajcová, J. Hamáčková J. Kouřil, P. Kozák: Values of Haematological Indices of Wels (Silurus glanis L.) in Relationship to the Level of Nutrition during the Pre-spawning Period. Acta vet. Brno 1998, 67: 235-242.

The goal of this paper was to evaluate the effect of different nutrition levels on condition and health expressed by means of selected haematological indices of both males and females of wels (Silurus glanis L.) during the pre-spawning period. For 2 months of the pre-spawning period, brood wels were separated into groups reared similarly but with different level of nutrition. The ratio of fodder fish biomass : wels biomass in 1995 was 3.2:1 in male group A; $1.1: 1$ in male group B; $2.6: 1$ in female group $C$ and $0.9: 1$ in female group $D$; while in 1997 this ratio was kept 2.3:1. 0.7:1 and $0.2: 1$ in female groups $\mathrm{A}, \mathrm{B}$ and $\mathrm{C}$. respectively.

Prior to the anticipated reproduction, haematological examination considered red blood count indices (red blood count - RBC. haematocrit - PCV, haemoglobin - $\mathrm{Hb}$, mean corpuscular volume - MCV. mean corpuscular haemoglobin - MCH, mean corpuscular haemoglobin concentration MCHC, erythrocyte sedimentation rate) and white blood count indices (leukocyte count - Leuko, leukogramme), along with concentration of total protein in blood plasma (TP). Altogether, 15 males and females were checked in 1995 while 18 females were checked in 1997.

Both males and females which had been reared during the 1995 and/or 1997 pre-spawning period with higher level of nutrition reached expressively higher relative weight gain and significantly higher total protein $(\mathrm{TP})$ in blood plasma $(\mathrm{P}<0.05: \mathrm{P}<0.01)$ compared to those with lower level of nutrition. Moreover, significantly higher $\mathrm{PCV} . \mathrm{Hb}$ and $\mathrm{MCH}(\mathrm{P}<0.05)$ were found in group of females with higher nutrition level in 1995. compared to those with a lower one. A significantly higher percentage of lymphocytes $(\mathrm{P}<0.05)$, as well as a lower percentage of granulocytes and their developmental forms $(\mathrm{P}<0.05)$ were found in a group of females with higher nutrition level in 1997 compared to those with lower nutrition levels. No significant differences were found in other haematological indices among the respective groups of brood wels. Results gained report for a more favourable condition of brood wels reared at higher nutrition level (ratio of fodder fish biomass : wels biomass 2.3:1 - 3.2:1) during the pre-spawning period and a higher non-specific disease resistance may be anticipated also. Relationships between nutrition level and values of production, haematological and reproductive characters of the fish under study were discussed.
\end{abstract}

Complete red blood count, complete white blood count, total plasma protein, males, females

Both the rearing and the nutrition level of fish during their pre-spawning period are important factors affecting quality of gametes and results of reproduction. Nevertheless, there are only sporadical references to the topic on individual fish species. The effect of nutrition level of reproductive traits were observed by Vachta et al. (1992) in tench, by Springate et al. (1985) in rainbow trout. Reproduction is considered among important physiological stress of the fish organism (Jeney and Jeney 1992; Svobodová et al. 
1997). During artificial reproduction, the physiological stress is multiplied by stress of handling. Organisms in good conditions can adapt better to this stress.

The goal of experiments performed in 1995 and repeated in 1997 was to evaluate the effect of different nutrition levels on productive and reproductive traits, condition and health of wels (Silurus glanis L.) during the pre-spawning period. As the broodstock is very valuable and kept in limited number, altogether 15 fish in 1995 and 18 fish in 1997 were studied. We report in this study the results of evaluation of the effect of different nutrition levels on condition and health expressed by means of selected haematological indices of both males and females of wels during the pre-spawning period. Relationships between values of haematological, production and reproductive traits of the fish under study are also discussed.

\section{Materials and Methods}

The broodstock was reared in experimental ponds of $800 \mathrm{~m}^{2}$ each during the pre-spawning period. Fish used for experiments were individually weighed and tagged intramuscularly by Fish Eagle passive integrated transponder (P.I.T.) tags. They were identified by means of a hand-held reader. Various ratios of fodder fish : broodstock biomass were used for wels feeding. The following species were used as fodder fish in 1995: common carp (Cyprinus carpio L.), gibel carp, goldfish (Carassius auratus L.) and crucian carp (C. carassius L.), tench (Tinca tinca L.), roach (Rutilus rutilus L.), rudd (Scardinius ervthrophthalmus L.), perch (Perca fluviatilis L.) and bream (Abramis brama L.). In 1997, the fodder fish were limited to rudd, roach and common carp.

In the 1995 experiment, the brood wels were separated into the following 4 groups and stocked on April 24 into experimental ponds:

group A - males with higher nutrition level (stocking biomass ratio of fodder fish : broodstock 3.2:1)

group B - males with lower nutrition level (1.1:1)

group C - females with higher nutrition level (2.6:1)

group D - females with lower nutrition level $(0.9: 1)$

Prior to the anticipated reproduction, i. e. June 26 and 29, fish were caught, identified, anaesthetized with Menocain, weighed and sampled for blood. Samples were taken from 15 specimen ( 5 males of groupA, 4 males of group B, 3 females of group C and 3 females of group D).

The 1997 experiment was carried out on females only and they were separated into 3 groups as followed:

group A - females with higher nutrition level (stocking biomass ratio of fodder fish : broodstock 2.3:1)

group B - females with lower nutrition level $(0.7: 1)$

group C - females with very low nutrition level $(0.2: 1)$

Fish were stocked on April 9. Prior to the anticipated reproduction, i. e. June 19, fish were caught, identified, anaesthetized with Menocain, weighed and the relative weight gain per day $\left(\% \cdot \mathrm{d}^{-1}\right)$ was calculated. Blood samples were taken from 18 specimen in total, i. e. 3 groups of 6 fish each.

Blood was sampled from a. et $\mathrm{v}$. caudalis. Heparin in amount of $50 \mathrm{IU}$ sodium heparin per $1 \mathrm{ml}$ blood was used for stabilization. Samples were used for determination of red blood count (RBC), haematocrit (PCV), haemoglobin $(\mathrm{Hb})$, mean corpuscular volume (MCV), mean corpuscular haemoglobin $(\mathrm{MCH})$, mean corpuscular haemoglobin concentration (MCHC), leukocyte count (Leuko), leukogramme and concentration of total protein in blood plasma (TP). Moreover, both male and female samples checked in 1995 were used to determine erythrocyte sedimentation rate. Methods followed the Unified Methods of Haematological Examination of Fish by S v obod ová et al. (1991). The concentration of total protein in blood plasma was determined refractometrically. Results were evaluated using $\mathrm{t}$-test in the STAT Plus software by VÚVeL Brno.

\section{Results}

A remarkably lower relative weight gain $\left(0.050\right.$ and $\left.0.079 \% \cdot \mathrm{d}^{-1}\right)$ was recorded for males and females, respectively, kept during the 1995 pre-spawning period at a lower nutrition level compared to those kept at the higher one $\left(0.182\right.$ and $0.253 \% \cdot \mathrm{d}^{-1}$ for males and females, respectively). Results of haematological indices of brood males and females of wels kept at differing nutrition levels are given in Tables 1 and 2. For both males and females at the higher nutrition level, higher total protein concentrations in blood plasma (40.4 \pm 6.10 and 38.5 $\pm 12.3 \mathrm{~g} \cdot \mathrm{l}^{-1}$, respectively) were recorded compared to those from the lower nutrition level 
$\left(26.8 \pm 5.28\right.$ and $27.6 \pm 1.27 \mathrm{~g} \cdot \mathrm{l}^{-1}$, respectively; Fig. 1). This difference was found significant for males $(\mathrm{P}<0.05)$. Moreover, significantly higher $\mathrm{PCV}, \mathrm{Hb}$ and $\mathrm{MCH}(\mathrm{P}<0.05)$ were found in group of females with higher nutrition level compared to those with a lower one. No significant differences were found in other red and white blood indices among the compared groups of brood wels.

Table 1

Haematological indices of Silurus glanis L. males reared at different nutrition levels during the pre-spawning period (June 26 and 29, 1995)

\begin{tabular}{|l|c|c|c|}
\hline \multirow{2}{*}{ Parameter } & \multirow{2}{*}{ Unit } & \multicolumn{2}{|c|}{ Nutrition Level } \\
\cline { 3 - 4 } & & $\begin{array}{c}\text { Higher }-\mathrm{A} \\
\text { mean } \pm \mathrm{SD}(\mathrm{n}=5)\end{array}$ & $\begin{array}{c}\text { Lower }-\mathrm{B} \\
\text { mean } \pm \mathrm{SD}(\mathrm{n}=4)\end{array}$ \\
\hline Fish body mass & $\mathrm{g}$ & $5990 \pm 1818$ & $4910 \pm 621$ \\
\hline Haematocrit $(\mathrm{PCV})$ & $\mathrm{l} \cdot \mathrm{l}^{-1}$ & $0.33 \pm 0.079$ & $0.38 \pm 0.022$ \\
\hline Erythrocytes $(\mathrm{RBC})$ & $\mathrm{T} \cdot \mathrm{l}^{-1}$ & $1.54 \pm 0.447$ & $1.60 \pm 0.284$ \\
\hline Haemoglobin $(\mathrm{Hb})$ & $\mathrm{g} \cdot \mathrm{l}^{-1}$ & $69.9 \pm 22.04$ & $71.1 \pm 4.83$ \\
\hline MCV & $\mathrm{fl}$ & $220 \pm 14.6$ & $245 \pm 51.7$ \\
\hline MCHC & $1 \cdot \mathrm{I}^{-1}$ & $0.21 \pm 0.030$ & $0.19 \pm 0.014$ \\
\hline MCH & $\mathrm{pg}$ & $45.1 \pm 5.25$ & $45.7 \pm 7.15$ \\
\hline Leukocytes (Leuko) & $\mathrm{G} \cdot \mathrm{I}^{-1}$ & $57.2 \pm 10.72$ & $54.0 \pm 22.86$ \\
\hline
\end{tabular}

Table 2

Haematological indices of Silurus glanis L. females reared at different nutrition levels during the pre-spawning period (June 26 and 29, 1995)

\begin{tabular}{|c|c|c|c|}
\hline \multirow[b]{2}{*}{ Parameter } & \multirow[b]{2}{*}{ Unit } & \multicolumn{2}{|c|}{ Nutrition Level } \\
\hline & & $\begin{array}{c}\text { Higher }-A \\
\text { mean } \pm S D(n=3)\end{array}$ & $\begin{array}{c}\text { Lower }-\mathrm{B} \\
\text { mean } \pm \mathrm{SD}(\mathrm{n}=3)\end{array}$ \\
\hline Fish body mass & $\mathrm{g}$ & $6470 \pm 2612$ & $7150 \pm 2940$ \\
\hline Haematocrit (PCV) & $1 \cdot 1^{-1}$ & $0.32 \pm 0.012 \mathrm{a}$ & $0.28 \pm 0.005 b$ \\
\hline Erythrocytes (RBC) & $\mathrm{T} \cdot \mathrm{I}^{-1}$ & $1.48 \pm 0.120$ & $1.55 \pm 0.116$ \\
\hline Haemoglobin $(\mathrm{Hb})$ & $g \cdot l^{-1}$ & $82.2 \pm 2.56 \mathrm{a}$ & $71.3 \pm 3.38 \mathrm{~b}$ \\
\hline $\mathrm{MCV}$ & fl & $215 \pm 15.7$ & $184 \pm 10.6$ \\
\hline $\mathrm{MCHC}$ & $1 \cdot 1^{-1}$ & $0.26 \pm 0.005$ & $0.25 \pm 0.008$ \\
\hline $\mathrm{MCH}$ & $\mathrm{pg}$ & $55.9 \pm 4.64 \mathrm{a}$ & $46.2 \pm 1.27 \mathrm{~b}$ \\
\hline Leukocytes (Leuko) & $G \cdot 1^{-1}$ & $78.3 \pm 18.37$ & $88.0 \pm 4130$ \\
\hline
\end{tabular}

The 1995 data were used as well to assess a sex-related difference in values of haematological indices. Within the fish kept at higher nutrition level, significantly higher both MCHC and $\mathrm{MCH}(\mathrm{P}<0.05)$ were found in females compared to males. Similarly, a significantly higher $\mathrm{MCH}$ of females $(\mathrm{P}<0.01)$ compared to that of males was found in the fish kept at lower nutrition level. Values of erythrocyte sedimentation rate of males and females of all groups under study are given in Fig. 2. In all cases, higher sedimentation rate was found for females compared to males. This difference was significant for fish kept at lower nutrition level within the 20 min time limit $(\mathrm{P}<0.05)$. reaching $22.1 \pm 4.28 \%$ for males and $32.7 \pm 2.72 \%$ for females.

In the 1997 pilot experiments, the highest relative weight gain $\left(0.119 \% \cdot \mathrm{d}^{-1}\right)$ was recorded for female group A reared at higher nutrition level, followed by female group B at 


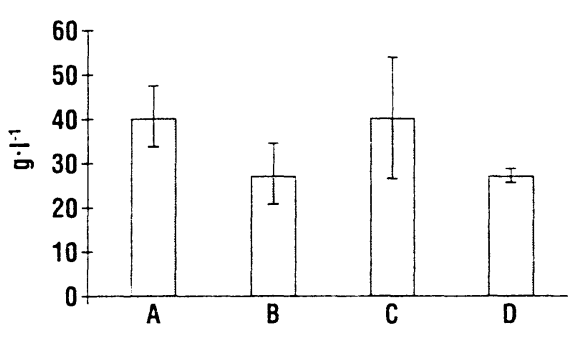

Fig. 1.

Total protein concentration in blood plasma of Silurus glanis L. males and females, reared at different nutrition levels during the pre-spawning period (June 26 and 29, 1995). $A$ - males at higher nutrition level, B - males at lower nutrition level, C - females at higher nutrition level, D - females at lower nutrition level.

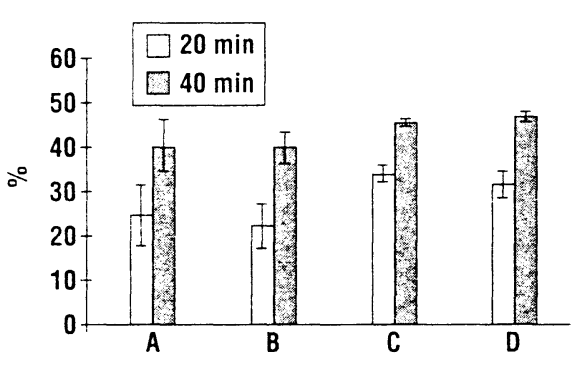

Fig. 2.

Erythrocyte sedimentation rate of Silurus glanis $\mathbf{L}$. males and females, reared at different nutrition levels during the pre-spawning period (June 26 and 29, 1995). A - males at higher nutrition level, B - males at lower nutrition level, C - females at higher nutrition level, D -females at lower nutrition level.

lower nutrition level $\left(0.020 \% \cdot \mathrm{d}^{-1}\right)$. For the female group $\mathrm{C}$, reared at the very low nutrition level, even a negative relative weight gain was found $\left(-0.023 \% \cdot \mathrm{d}^{-1}\right)$.

Results of haematological investigation of wels females kept at three levels of nutrition are given in Table 3 and Fig. 3. Significant differences among the groups of fish differring

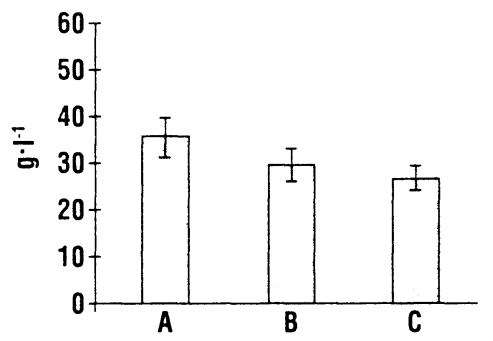

Fig. 3.

Total protein concentration in blood plasma of Silurus glanis L. females reared at different nutrition levels during the pre-spawning period (June 19, 1997). A - higher nutrition level, B - lower nutrition level, $\mathrm{C}$ - very low nutrition level. with nutrition level were found for total protein concentration in blood plasma (TP). The highest TP was registered for female group A with higher nutrition level (33.1 $\left.\pm 4.92 \mathrm{~g} \cdot \mathrm{l}^{-1}\right)$, the lowest one for female group $C$ of the lowest nutrition level (24.1 $\left.\pm 3.19 \mathrm{~g} \cdot \mathrm{l}^{-1}\right)$. This difference was found significant between $\mathrm{A}$ and $\mathrm{C}$ groups, as well as between $\mathrm{A}$ and $\mathrm{B}$ group, the latter with lower nutrition level $\left(27.0 \pm 2.40 \mathrm{~g} \cdot \mathrm{l}^{-1}\right)$ $(\mathrm{P}<0.05)$. A significantly lower mean corpuscular volume (MCV) was found in female group $\mathrm{A}$ of higher nutrition level compared to $\mathrm{B}$ and $\mathrm{C}$ groups $(\mathrm{P}<0.05)$. Significantly higher percentage of lymphocytes $(\mathrm{P}<0.05)$ was registered for $\mathrm{A}$ female group compared to B female group of lower nutrition level. Similarly, the female A group was found to have a lower percentage of granulocytes and their developmental forms (myelocytes, metamyelocytes, neutrophile granulocytes - band forms and segmented forms) compared to $B(P<0.01)$ and $C \quad(P<0.05)$ groups. No significant differences were found in other indices of red and white blood count among the respective groups of female wels.

\section{Discussion}

An important period of brood fish preparation for reproduction starts after overwintering. In case of brood wels kept in ponds for artificial reproduction, the pre-spawning period is considered extremely important for reproductive results, and above all from the point of view of fish recovering after reproduction. The cause is mainly in the character of changes 
Table 3

Haematological indices of Silurus glanis L. females reared at differring nutrition levels during the pre-spawning period (June 19, 1997)

\begin{tabular}{|c|c|c|c|c|}
\hline \multirow[b]{2}{*}{ Index } & \multirow[b]{2}{*}{ Unit } & \multicolumn{3}{|c|}{ Nutrition Level } \\
\hline & & $\begin{array}{c}\text { Higher }-A \\
\text { mean } \pm S D(n=6)\end{array}$ & $\begin{array}{c}\text { Lower - }- \\
\text { mean } \pm S D(n=6)\end{array}$ & $\begin{array}{c}\text { Very low }-C \\
\text { mean } \pm S D(n=6)\end{array}$ \\
\hline Fish body mass & $\mathrm{g}$ & $8330 \pm 3093$ & $8520 \pm 3740$ & $8190 \pm 3962$ \\
\hline Haematocrit (PCV) & $1.1^{-1}$ & $0.28 \pm 0.054$ & $0.32 \pm 0.009$ & $0.35 \pm 0.038$ \\
\hline Erythrocytes (RBC) & T. $1^{-1}$ & $1.59 \pm 0.324$ & $1.53 \pm 0.117$ & $1.73 \pm 0.158$ \\
\hline Haemoglobin $(\mathrm{Hb})$ & g..$^{-1}$ & $74.8 \pm 11.39$ & $79.0 \pm 3.96$ & $86.7 \pm 9.51$ \\
\hline $\mathrm{MCV}$ & $\mathrm{fl}$ & $178 \pm 7.5^{\mathrm{a}}$ & $208 \pm 15.6^{\mathrm{b}}$ & $203 \pm 14.4^{b}$ \\
\hline $\mathrm{MCHC}$ & $1.1^{-1}$ & $0.27 \pm 0.034$ & $0.25 \pm 0.007$ & $0.25 \pm 0.017$ \\
\hline $\mathrm{MCH}$ & pg & $48.0 \pm 6.40$ & $52.0 \pm 4.68$ & $50.4 \pm 4.97$ \\
\hline Leukocytes (Leuko) & G. $1^{-1}$ & $88.5 \pm 38.95$ & $55.6 \pm 24.67$ & $58.4 \pm 10.69$ \\
\hline Lymphocytes & $\begin{array}{c}\% \\
\text { G. } 1^{-1} \\
\end{array}$ & $\begin{array}{l}93.25 \pm 2.983^{\mathrm{a}} \\
82.74 \pm 36.177\end{array}$ & $\begin{array}{l}84.42 \pm 5.342^{b} \\
47.44 \pm 21.128\end{array}$ & $\begin{array}{l}88.68 \pm 4.559^{\mathrm{ab}} \\
52.01 \pm 11.116\end{array}$ \\
\hline Monocytes & $\begin{array}{c}\% \\
\text { G. } 1^{-1}\end{array}$ & $\begin{array}{l}1.42 \pm 1.742 \\
1.13 \pm 1.203\end{array}$ & $\begin{array}{l}2.50 \pm 1.528 \\
1.37 \pm 1.324\end{array}$ & $\begin{array}{l}1.42 \pm 0.932 \\
0.78 \pm 0.547\end{array}$ \\
\hline Myelocytes & $\begin{array}{c}\% \\
\text { G. } .^{-1}\end{array}$ & $\begin{array}{l}2.00 \pm 0.764 \\
1.63 \pm 0.614\end{array}$ & $\begin{array}{l}3.92 \pm 1.902 \\
2.24 \pm 1.211\end{array}$ & $\begin{array}{l}2.63 \pm 1.293 \\
1.53 \pm 0.724\end{array}$ \\
\hline Metamyelocytes & $\begin{array}{c}\% \\
\text { G. } .^{-1}\end{array}$ & $\begin{array}{l}2.67 \pm 1.572 \\
2.52 \pm 2.651\end{array}$ & $\begin{array}{l}8.00 \pm 4.481 \\
3.97 \pm 2.736\end{array}$ & $\begin{array}{l}7.02 \pm 3.294 \\
3.94 \pm 1.639\end{array}$ \\
\hline $\begin{array}{l}\text { Neutrophile } \\
\text { granulocytes - band } \\
\text { forms }\end{array}$ & $\begin{array}{c}\% \\
\text { G. } 1^{-1}\end{array}$ & $\begin{array}{l}0.33 \pm 0.553 \\
0.26 \pm 0.393\end{array}$ & $\begin{array}{l}1.08 \pm 0.731 \\
0.08 \pm 0.186\end{array}$ & $\begin{array}{l}0.08 \pm 0.186 \\
0.04 \pm 0.097\end{array}$ \\
\hline $\begin{array}{l}\text { Neutrophile } \\
\text { granulocytes - } \\
\text { segmented forms }\end{array}$ & $\begin{array}{c}\% \\
\text { G. } 1^{-1}\end{array}$ & $\begin{array}{l}0.33 \pm 0.745 \\
0.23 \pm 0.507\end{array}$ & $\begin{array}{l}0.08 \pm 0.186 \\
0.05 \pm 0.119\end{array}$ & $\begin{array}{l}0.17 \pm 0.236 \\
0.11 \pm 0.161\end{array}$ \\
\hline $\begin{array}{l}\text { Granulocytes and } \\
\text { their developmental } \\
\text { forms }\end{array}$ & $\begin{array}{c}\% \\
\mathrm{G} . \mathrm{I}^{-1}\end{array}$ & $\begin{array}{l}4.58 \pm 2.422^{a} \\
4.64 \pm 2.987\end{array}$ & $\begin{array}{c}13.08 \pm 4.325^{b} \\
6.78 \pm 3.774\end{array}$ & $\begin{array}{l}9.75 \pm 4.376^{b} \\
5.63 \pm 2.370\end{array}$ \\
\hline
\end{tabular}

Values with superscript ${ }^{\mathrm{a}}$ and ${ }^{\mathrm{b}}$ express significant difference $(\mathrm{P}<0.05, \mathrm{P}<0.01$, respectively) between groups $\mathrm{A}$ and $\mathrm{B}$, between $\mathrm{A}$ and $\mathrm{C}$ and between $\mathrm{B}$ and $\mathrm{C}$.

of gonadosomatic index. In wels females, it has a sheer-growing course in the last one or one-and-half month prior to spawning (Kouřil et al. 1981). Rearing of the respective groups of wels males and females in ponds was performed and evaluated in spring 1995 and repeatedly in spring 1997. All groups were kept under the same conditions with the only difference being in nutrition level. This was reflected in the daily relative weight gain, $i$.e. the higher nutrition level (higher ratio of fodder fish biomass : broodstock biomass), the higher was the daily relative weight gain. With a group of females kept at a very low nutrition level $(0.2: 1)$, there was even a negative relative weight gain. 
Apart from these production traits, the broodfish condition and health was checked by means of haematological indices at the end of the pre-spawning period, i. e. prior to the anticipated reproduction. The concentration of total protein in blood plasma is considered one of the most important indices for assessment of condition and health of fish in feeding experiments (Svobodová and Párová 1977; Jirásek et al. 1993; Kolářová et al. 1998). Our evaluation of wels males and females kept at different nutrition levels also showed significant differences in total protein concentration in blood plasma, with the benefit for groups kept at higher nutrition level. It was proved repeatedly in 1995 for males and in 1997 for females. Values of other haematological indices also evidenced a better condition and health of brood wels kept at higher nutrition level during the pre-spawning period. This can be exemplified on significantly higher values of haematocrit, haemoglobin concentration and mean corpuscular haemoglobin in a group of females with higher nutrition level compared to those with lower nutrition level at the end of 1995 pre-spawning period. As a significantly higher percentage of lymphocytes and a lower percentage of granulocytes and their developmental forms were found in a group of females with higher nutrition level in 1997 compared to those with lower nutrition levels, this group may be considered having a higher non-specific resistance.

The data reported and discussed in this study evidence unambiguously for more favourable condition and health of wels reared at higher nutrition level compared to those kept at lower nutrition level. Despite of these facts, no differences in female reproductive traits of the respective groups were proven repeatedly, e. g. relative fecundity and mean weight of 1 egg did not differ significantly within the two (1995) or three (1997) different nutrition levels (Kouřil et al. 1996; Hamáčková et al. 1998). Ha máčková et al. (1998) stated that the gonad weight of wels females kept at three various nutrition levels during the pre-spawning period did not increase in consequence of food intake only but also due to utilization of supply substances. In contrary, it was proven for male group with the higher nutrition level in 1995 that there was a highly significant $(\mathrm{P}<0.01)$ difference in relative count of stripped spermatozoa (Kouřil et al. 1996).

Though the number of fish analyzed in 1995 was very low, we tried to compare the values of haematological indices of wels males and females. Higher erythrocyte sedimentation rate in all groups of females compared to males was in accordance with data in the literature (Sabioncello et al. 1969; Svobodová et al. 1981; Habekovič 1987). A significant difference in erythrocyte sedimentation rate between males and females of groups at lower nutrition level is also worth of mention. This difference was significant $(\mathrm{P}<0.01)$ within the 20 min limit (males $22.1 \pm 4.28 \%$, females $32.7 \pm 2.72 \%$ ).

\section{Hematologické ukazalete sumců (Silurus glanis L.) ve vztahu $\mathrm{k}$ výživě v předvýtěrovém období}

Cílem práce bylo zhodnotit vliv různých úrovní výživy $\mathrm{v}$ předvýtěrovém období na kondiční a zdravotní stav vyjádřený vybranými hematologickými parametry mličáků a jikernaček sumce velkého (Silurus glanis L.). Generační sumci byli po dobu zhruba 2 měsíců předvýtěrového období rozděleni do skupin odchovávaných za stejných podmínek na různé úrovni výživy. Poměr biomasy krmných ryb ku biomase sumcủ při nasazení do rybničků byl v roce 1995 u skupiny A-mlíčáci 3.2:1; B-mličáci 1.1:1; C-jikernačky 2.6:1; D-jikernačky $0.9: 1$; v roce 1997 u skupiny A-jikernačky 2.3:1; B-jikernačky 0.7:1; Cjikernačky 0.2:1. Před předpokládaným výtěrem bylo provedeno vyšetření červeného (red blood count - RBC, hematokritová hodnota - PCV, hemoglobin - Hb, střední objem erytrocytu - MCV, hemoglobin erytrocytu - MCH, střední barevná koncentrace - MCHC, 
rychlost sedimentace erytrocytů) a bílého krevního obrazu (počet leukocytů - Leuko, leukogram) a byla stanovena koncentrace celkových bílkovin v krevní plazmě (TP). Celkem bylo vyšetřeno 15 mlíčákủ a jikernaček v roce 1995 a 18 jikernaček v roce 1997.

U mličákủ a jikernaček odchovávaných v předvýtěrovém období 1995 a 1997 při vyšších úrovních výživy bylo dosaženo výrazně vyššího relativního př́rủstku hmotnosti a signifikantně vyššího obsahu TP v krevní plazmě $(P<0.05 ; P<0.01)$ ve srovnání se skupinami odchovávanými při nižších úrovních výživy. V roce 1995 byla u skupiny jikernaček s vyšší úrovní výživy zjištěna signifikantně vyšší hodnota $\mathrm{PCV}, \mathrm{Hb}$, a MCH $(\mathrm{P}<0.05)$ ve srovnání $s$ hodnotami zjištěnými u jikernaček s nižší úrovní výživy. V roce 1997 bylo u skupiny jikernaček s vyšší úrovní výživy zjištěno signifikantně vyčší procentuální zastoupení lymfocytů $(\mathrm{P}<0.05)$ a nižší procentuální zastoupení granulocytů a jejich vývojových forem $(\mathrm{P}<0.05)$ ve srovnání se skupinami s nižši úrovní výživy. Mezi hodnotami ostatních sledovaných hematologických parametrů jednotlivých skupin generačních sumců nebyly nalezeny signifikantní diference. Získané výsledky svědčí o přiznivější kondici a lze předpokládat i vyšší nespecifickou odolnost u generačních sumců odchovávaných v předvýtěrovém období na vyšší úrovni výživy (poměr biomasy krmných ryb ku biomase sumců 2.3:1 - 3.2:1). Diskutovány byly vztahy mezi úrovní výživy a hodnotami produkčních, hematologických a reprodukčních ukazatelů sledovaných ryb.

\section{Acknowledgements}

The authors are grateful to Mrs. Anna Kocová for haematological examination of the fish. This research was supported as Project No.5193 by the National Agency for Agricultural Research. Ministry of Agriculture of the Czech Republic. The research performed followed the regulations of the Ethical Board of Animal Welfare Protection of the Research Institute of Fish Culture and Hydrobiology, University of South Bohemia at Vodñany.

\section{References}

HABEKOVIC. D. 1987: The blood properties of the wels (Silurus glanis L.). Ichthyologia 19: 77-87

HAMÁĆKOVÁ, J., KOZÁK, P., KOUŘIL, J. 1998: Vliv intenzity výživy jikernaček sumce velkého (Silurus glanis) na produkční a reprodukční ukazatele. Sborník III. České ichtyologické konference, VÚRH JU Vodňany, pp. 197-204

JENEY.Z., JENEY, G. 1992: Primary and secondary stress responses of common carp (Cyprinus carpio L.) caused by artificial propagation. Reprodukce ryb, RIFCH Vodñany, pp. 27-28

JIRÁSEK, J., PALÁĆKOVÁ, J., MAREŚ, J. 1993: The effect of a different quality of feed on selected indicators of the internal environment of the rainbow trout. Ichthyohaematology 3rd Conference, RIFCH Vodňany, pp. 4045

KOLÁR̉OVÁ, J.. SVOBODOVÁ, Z., VAJCOVÁ. V., HAMÁČKOVÁ, J., KOUŘIL. J. 1998: Vliv intenzity výživy jikernaček sumce velkého (Silurus glanis L.). na fyziologické ukazatele. Sborník III. Ceské ichtyologické konference, VÚRH JU Vodñany, pp. 205-208.

KOUŘIL, J.. HAMÁCKKOVÁ. J., KEPR, T. 1981: Umělý výtěr sumce. Reprodukce, genetika a hybridizace ryb, SZS Ichtyologická sekce. VÚRH Vodñany. pp. 128 - 134

KOUŘIL, J., HAMÁČKOVÁ. J., KOZÁK. P. 1996: Vliv různé úrovně výživy generačních sumců obojího pohlaví $v$ předvýtěrovém obdobi na produkční a reprodukční ukazatele. Sborník II. Ceské ichtyologické konference, VÚRH JU Vodñany. pp. 195-200

SABIONCELLO, J. et al. 1969: Použití současných zpủsobủ odchovu kapřiho (Cyprinus carpio L.) a sumčího (Silurus glanis L.) plůdku na rybníkáŕstvích Chorvatské republiky. Publikace zootech. oboru AF VŠZ v Brně rybářská specializace, pp. 95-106

SPRINGATE. J. R. C., BROMAGE, N. R., CUMARANATUNGA, P. R. T. 1985: The effect of different ration on fecundity and eggs quality in the rainbow trout (Salmo gairdneri). In: Cowey. C. B.. Mackye, A. M.. Bell, J. G. (eds.): Nutrition and feeding in fïsh. Academic Press London, pp. $371-393$

SVOBODOVÁ. Z.. KOLÁR̉OVÁ. J. KOUŘIL. J., HAMÁČKOVÁ, J. VYKUSOVÁ. B., KALÁB. P. 1997: Haematological investigations in Silurus glanis L. females during pre and postspawning period. Pol. Arch. Hydrobiol. 44: 67-81

SVOBODOVÁ. Z., KOUŘIL, J., HAMÁČKOVÁ, J. 1981: Vliv pohlaví na některé hematologické a biochemické hodnoty u ryb. Reprodukce, genetika a hybridizace ryb, VÚRH Vodňany, pp.11-17 
SVOBODOVÁ, Z., PÁROVÁ, J. 1977: Využití některých fyziologických ukazatelů ryb ke zhodnocení krmných pokusů. Buletin VÚRH Vodňany, 13: $12-19$

SVOBODOVÁ, Z., PRAVDA, D., PALÁĆKOVÁ, J., 1991: Unified methods of haematological examination of fish. RIFCH Vodñany, 31pp.

VACHTA, R., KOUŘIL, J. HAMÁCKKOVÁ, J. 1992: The influence of different environmental conditions in rearing of tench (Tinca tinca) females during pre-spawning period on condition parameters and results of induced artificial propagation with carp pituitary and syntetic $\mathrm{Gn}-\mathrm{RH}$ analogue. Reprodukce ryb, RIFCH Vodňany. pp. 61-64 